\title{
Proceeding
}

Supplementary Issue: Summer Conferences of Sports Science. First International Conference in Iraq on Sport for Peace, 4 April 2019. Baghdad Science Institute, Baghdad, Iraq.

\section{An analytical study of drinking stations according to the biochemical variables of the marathon runners in Iraq}

\author{
MOKHALAD DHEYAA ABDULRASOOL $\left.{ }^{1}\right]$, ALI AHMED ALAWADY1 , AHMED ADNAN KHAFEEF ${ }^{2}$ \\ ${ }^{1}$ College of Education, University of AL-Qadisiyah, Iraq \\ ${ }^{2}$ College of Engineering, University of AL-Qadisiyah, Iraq
}

\begin{abstract}
This study aims at identifying the differences, correlative relations, and the contribution percentage between the biochemical variables according to the drinking stations of the Marathon race in Iraq 2018. The sample was (225) runners. They have been chosen intentionally through choosing the first runners who were five. The researcher used the descriptive approach and correlations. The findings of the study have a huge effect on the biochemical variables (Na.Ca.Mg.K). The effort of the race leads to the decrease of the level of the biochemical variables in comparison to the levels before the effort. But it remains within the natural boundaries during the effort according to the race power and burden. Keywords: Running; Race power; Athletics; Effort.
\end{abstract}

\section{Cite this article as:}

Abdulrasool, M.D., Alawady, A.A., \& Khafeef, A.A. (2019). An analytical study of drinking stations according to the biochemical variables of the marathon runners in Iraq. Journal of Human Sport and Exercise, 14(5proc), S2142-S2149. doi:https://doi.org/10.14198/jhse.2019.14.Proc5.34

Corresponding author. College of Education, University of AL-Qadisiyah, Iraq.

E-mail: beh.ranibar.mc@gmail.com

Supplementary Issue: Summer Conferences of Sports Science. First International Conference in Iraq on Sport for Peace, 4 April 2019. Baghdad Science Institute, Baghdad, Iraq.

JOURNAL OF HUMAN SPORT \& EXERCISE ISSN 1988-5202

(c) Faculty of Education. University of Alicante

doi:10.14198/jhse.2019.14.Proc5.34 


\section{INTRODUCTION}

Marathon activity is considered as the real reflection of athletic culture development of various countries in the modern world. Marathon in Iraq related to the society health and the competition reaches to the highest level that depends on close relation with the special tolerance, which is compensated by salts, glucose and suitable diets to fit for the nature of the activity. The increase of the sweating during the exercise using the energy of the body, it increases because of the performance tight level. It reaches to (maximum - below maximum) when the high temperature or the wet weather. It is advisable that runners take the necessary liquid from special drinking stations. We always find any competitor's ability of success depends on the function and level of body competence. It determines the ability to keep liquids and energy in the different climate circumstances of Iraq and reaching these stations lead to win of the activity (Arthac ,2001). It is possible to say that the organizational and administrative work correlated and interrelated with the runner's competence and the climate circumstances during the performance which affects in the interchanging relation within it. The good administrative organization leads to the desired target that is compensation of liquid and the lost salts from the body, which causes the runner's exhaustion, functional incompetence of the body organs, and inability to reach an appropriate timing to reach the end of the race. The importance of the study lies in covering important aspects such as reveal drinking locations according to the biochemical variables to Marathon runners in Iraq and provide the specialists with necessary data of these variables, which works as a basis of promoting, achieving better accomplishments.

\section{THE STUDY PROBLEM}

Marathon runners' usually race in streets, squares, roads, and forests sometimes with the existence of natural barriers. For carrying out this competition, there should provide safety for the runners and providing the necessary medical supplies from administrating and organization of drinking stations by the specialists, administrative, and specialist medics. Through the survey of expert's opinions, a specialist in the field, trainers, and supervisors of the activity, we found that organizational administration of the drinking location was unsuccessful in determining the location and the materials of it according to the biochemical variables of the runners. It leads to the withdrawal of most of the runners during the competition (Jabes, 1984). The researcher is looking forward to dealing with an analytical study of these stations according to the variables of the activity in Iraq.

\section{THE STUDY OBJECTIVES}

The study aims at identifying the differences, the correlative relations, and percentage of contribution between the biochemical variables according to the drinking stations in the marathon race.

\section{THE STUDY HYPOTHESIS}

There are incorporeal differences in the correlative relations and the high contribution percentage between the biochemical variables before effort and the different stations of the runners in the Marathon race (Edington, 1987).

\section{THE STUDY LIMITATIONS}

Human: The Marathon racers of 2018.

Time: the period from 27-2-2019 to 30-4-209. 
Place: the playground of faculty of Physical Education and Athletic Sciences / University of Baghdad.

\section{THE STUDY METHODS}

The researcher uses the descriptive approach and correlative relations to achieve the study objectives (Robert, 1997).

\section{THE STUDY SAMPLE}

The study sample includes (225) Marathon runners of 2018. The sample is chosen in intentionally of the first five runners that represent $(2.2 \%)$ of the runners. The runners' description is identified in the rest time as it is shown in table (3-1).

Table 1. Represents the description of the study sample.

\begin{tabular}{|l|l|l|l|l|l|}
\hline No. & Variables & Mean & $\begin{array}{l}\text { Standard } \\
\text { deviation }\end{array}$ & Mode & skewness \\
\hline 1 & Age (year) & 26.75 & 0.957 & 26 & 0.855 \\
\hline 2 & Training age (year) & 9.25 & 0.816 & 9 & 0.212 \\
\hline 3 & Weight (Kg) & 67.3 & 0.816 & 67 & 0.004 \\
\hline 4 & Height (cm) & 1.692 & 0.008 & 1.69 & 0.001 \\
\hline
\end{tabular}

\section{THE STUDY EQUIPMENT, DEVICES, AND TOOLS}

Data gathering foreign and Arabic references, specialized experts, observations and assistant teamwork*.

\section{THE DEVICES AND TOOLS USED}

(5) Treadmills, South Korean (HP) laptop, Chinese Cooling box, Rest meter for measuring players' height and weight, medical supplies (needle; $5 \mathrm{ml}$, cannula, sterilizer, plastic pipes, medical cotton, plaster).

*Medical staff: Zuhair Saleh Mahmud; Doctor, Assist. Lecturer. Amal Rasheed Farhan; medical chemistry, Specialized Noor Alsabah Lab. In Baghdad, Hutham Ismail; senior practitioner, IbnAlhaitham Hospital.

\section{STUDY FIELD PROCEDURES}

\section{The biochemical variables measurements}

Blood samples $(3 \mathrm{ml})$ are collected from each player before and after the body effort (at each drinking station before drinking and after drinking bottles). The blood sample was taken by the medical staff* from a vein at hand without using pressure tie then he continues his run (Jamshidinaeini et al, 2016). The blood Transferred into blood pipes numbered from (1-8) for each player tagged with the name recorded in the registration form. ${ }^{* *}$ After the completion of each blood sample placed into a special cooling box and sent to the lab. ***

\section{The exploratory experiment}

The researcher conducts an exploratory visit on (10-4-2019) 9.00 am in the playground of the faculty of Physical Education and Sports Sciences - University of Baghdad, Iraq for runners out of the study samples (Hamada, 2001). They have been chosen intentionally to identify the difficulties and problems which the researcher may face at carrying out the work and to know the competence of the assistant teamwork to the nature of the work. 


\section{The primary experiment}

The researcher players' approval and their coaches to take blood samples and record the test. He also gets the approval of the Iraqi Athletic Union and the Faculty of Physical Education and Sport Sciences - the University of Baghdad to experiment using tools, devices, and place (Australia sports Medicine foundation, 1994). The work starts on (24-4-2019) 9.00am through taking blood samples of (3ml) from each runner (Alawi \& Abdulfatah, 1988). The blood is taken by medical staff from the vein of the hand of the players without using the pressure tie. The blood placed into pipes with by the name of the player and the amount of blood taken (Giton \& Hall, 1997). The test of run on the treadmill takes place in the field and not in the close hall to observe the environmental circumstances according to the period allocated for each player in the marathon. Blood sample is taken before each drinking station on specified locations according to the international law of marathon. After completing the process, the blood sample placed in pipes and placed in a cool box and sent to the lab. to know the biochemical measurements for each runner. ${ }^{* *}$ The measurements are documented in the registration form for each runner. ${ }^{*}$ The blood samples are (10); one before the test and without effort, and (7) during the test of run-through placing the hand on the handle of the treadmill, and the last one after the test immediately during body high effort. After each blood sample in drinking station, the player is given bottle of drink $(440 \mathrm{ml}$; containing $3.14 \mathrm{mg} / \mathrm{L}$ of $\mathrm{Ca}, 1.11 \mathrm{mg} / \mathrm{L}$ of $\mathrm{Mg}, 4.9 \mathrm{mg} / \mathrm{L}$ of $\mathrm{Na}$, and $1.53 \mathrm{mg} / \mathrm{L}$ of K) (Khalil Mohammed, 2008).

\section{STATISTICS}

We used the (SPSS) to process raw data.

Table 2. The statistical procedures before, during, and in the end of the race for the runners 'biochemical variables.

\begin{tabular}{|c|c|c|c|c|c|c|c|c|c|c|c|c|c|}
\hline \multirow{4}{*}{$\begin{array}{l}\mathrm{N} \\
0\end{array}$} & Variables & \multicolumn{4}{|c|}{$\mathrm{Na}+$ variable } & \multicolumn{4}{|l|}{ M.MOL/L } & \multicolumn{4}{|c|}{$\mathrm{K}+$ Variables using M.MOI/L } \\
\hline & $\begin{array}{l}\text { Arithmeti } \\
\text { cal values }\end{array}$ & \multicolumn{2}{|c|}{ Station } & \multicolumn{2}{|c|}{$\begin{array}{l}\text { Next } \\
\text { station }\end{array}$} & \multirow[t]{3}{*}{$\begin{array}{l}\text { Calculated } \\
\text { T value }\end{array}$} & \multirow[t]{3}{*}{$\begin{array}{l}\text { Significanc } \\
\text { e level }\end{array}$} & \multicolumn{2}{|c|}{ Station } & \multicolumn{2}{|c|}{$\begin{array}{l}\text { Next } \\
\text { station }\end{array}$} & \multirow[t]{3}{*}{$\begin{array}{l}\text { calculat } \\
\text { ed T v }\end{array}$} & \multirow[t]{3}{*}{$\begin{array}{l}\text { Significanc } \\
\text { e level }\end{array}$} \\
\hline & \multirow{2}{*}{ Station } & & & & & & & & & & & & \\
\hline & & C & $A$ & C & $A$ & & & C & $A$ & C & $A$ & & \\
\hline 1 & $\begin{array}{l}\text { Before } \\
\text { effort- } \\
\text { station } 1\end{array}$ & 133.0 & $\begin{array}{l}5.33 \\
9\end{array}$ & 140.0 & $\begin{array}{l}5.78 \\
8\end{array}$ & 1.988 & $\begin{array}{l}\text { insignifican } \\
\text { ce }\end{array}$ & $\begin{array}{l}3.86 \\
0\end{array}$ & $\begin{array}{l}0.35 \\
1\end{array}$ & $\begin{array}{l}4.50 \\
0\end{array}$ & $\begin{array}{l}0.50 \\
0\end{array}$ & 2.343 & $\begin{array}{l}\text { insignifican } \\
\text { ce }\end{array}$ \\
\hline 2 & $\begin{array}{l}\text { Station 1- } \\
\text { station } 2\end{array}$ & 140.0 & $\begin{array}{l}5.78 \\
8\end{array}$ & 141.0 & $\begin{array}{l}6.51 \\
9\end{array}$ & 0.256 & $\begin{array}{l}\text { insignifican } \\
\mathrm{ce}\end{array}$ & $\begin{array}{l}4.50 \\
0\end{array}$ & $\begin{array}{l}0.50 \\
0\end{array}$ & $\begin{array}{l}4.70 \\
0\end{array}$ & $\begin{array}{l}0.75 \\
8\end{array}$ & 0.492 & $\begin{array}{l}\text { insignifican } \\
\mathrm{ce}\end{array}$ \\
\hline 3 & $\begin{array}{l}\text { Station2- } \\
\text { station3 }\end{array}$ & 141.0 & $\begin{array}{l}6.51 \\
9\end{array}$ & 142.0 & $\begin{array}{l}4.69 \\
0\end{array}$ & 0.278 & $\begin{array}{l}\text { insignifican } \\
\text { ce }\end{array}$ & $\begin{array}{l}4.70 \\
0\end{array}$ & $\begin{array}{l}0.75 \\
8\end{array}$ & $\begin{array}{l}4.90 \\
0\end{array}$ & $\begin{array}{l}0.74 \\
2\end{array}$ & 0.422 & $\begin{array}{l}\text { insignifican } \\
\mathrm{ce}\end{array}$ \\
\hline 4 & $\begin{array}{l}\text { Station3- } \\
\text { station4 }\end{array}$ & 142.0 & $\begin{array}{l}4.69 \\
0\end{array}$ & 143.0 & $\begin{array}{l}3.39 \\
1\end{array}$ & 0.386 & $\begin{array}{l}\text { insignifican } \\
\mathrm{ce}\end{array}$ & $\begin{array}{l}4.90 \\
0\end{array}$ & $\begin{array}{l}0.74 \\
2\end{array}$ & $\begin{array}{l}5.00 \\
0\end{array}$ & $\begin{array}{l}0.79 \\
1\end{array}$ & 0.206 & $\begin{array}{l}\text { insignifican } \\
\mathrm{ce}\end{array}$ \\
\hline 5 & $\begin{array}{l}\text { Station4- } \\
\text { station5 }\end{array}$ & 143.0 & $\begin{array}{l}3.39 \\
1\end{array}$ & 145.0 & $\begin{array}{l}3.08 \\
2\end{array}$ & 0.976 & $\begin{array}{l}\text { insignifican } \\
\text { ce }\end{array}$ & $\begin{array}{l}5.00 \\
0\end{array}$ & $\begin{array}{l}0.79 \\
1\end{array}$ & $\begin{array}{l}5.10 \\
0\end{array}$ & $\begin{array}{l}0.65 \\
2\end{array}$ & 0.218 & $\begin{array}{l}\text { insignifican } \\
\mathrm{ce}\end{array}$ \\
\hline 6 & $\begin{array}{l}\text { Station5- } \\
\text { station5 }\end{array}$ & 145.0 & $\begin{array}{l}3.08 \\
2\end{array}$ & 146.0 & $\begin{array}{l}2.73 \\
9\end{array}$ & 0.542 & $\begin{array}{l}\text { insignifican } \\
\text { ce }\end{array}$ & $\begin{array}{l}5.10 \\
0\end{array}$ & $\begin{array}{l}0.65 \\
2\end{array}$ & $\begin{array}{l}5.30 \\
0\end{array}$ & $\begin{array}{l}0.44 \\
7\end{array}$ & 0.566 & $\begin{array}{l}\text { insignifican } \\
\mathrm{ce}\end{array}$ \\
\hline 7 & $\begin{array}{l}\text { Station6- } \\
\text { station77 }\end{array}$ & 146.0 & $\begin{array}{l}2.73 \\
9\end{array}$ & 149.0 & $\begin{array}{l}1.41 \\
4\end{array}$ & 2.176 & $\begin{array}{l}\text { insignifican } \\
\text { ce }\end{array}$ & $\begin{array}{l}5.30 \\
0\end{array}$ & $\begin{array}{l}0.44 \\
7\end{array}$ & $\begin{array}{l}5.50 \\
0\end{array}$ & $\begin{array}{l}0.50 \\
0\end{array}$ & 0.667 & $\begin{array}{l}\text { insignifican } \\
\mathrm{ce}\end{array}$ \\
\hline 8 & $\begin{array}{l}\text { Station7- } \\
\text { end of } \\
\text { effort }\end{array}$ & 149.0 & $\begin{array}{l}1.41 \\
4\end{array}$ & $\begin{array}{l}149.2 \\
00\end{array}$ & $\begin{array}{l}2.95 \\
0\end{array}$ & 0.137 & $\begin{array}{l}\text { insignifican } \\
\text { ce }\end{array}$ & $\begin{array}{l}5.50 \\
0\end{array}$ & $\begin{array}{l}0.50 \\
0\end{array}$ & $\begin{array}{l}5.48 \\
0\end{array}$ & $\begin{array}{l}0.61 \\
4\end{array}$ & 0.056 & $\begin{array}{l}\text { insignifican } \\
\text { ce }\end{array}$ \\
\hline $\mathrm{N}$ & Variables & $\mathrm{Na}+\mathrm{va}$ & able & & & M.MOL/L & & & & $\mathrm{K}+\mathrm{V}$ & iables & sing $M . M C$ & \\
\hline 0 & $\begin{array}{l}\text { Statistics } \\
\text { Station }\end{array}$ & Station & & Next s & & $\begin{array}{l}\text { calculat } \\
\text { ed } T\end{array}$ & $\begin{array}{l}\text { Significanc } \\
\text { e level }\end{array}$ & Station & & Next & ation & $\begin{array}{l}\text { calculat } \\
\text { ed } T\end{array}$ & $\begin{array}{l}\text { Significanc } \\
\text { e level }\end{array}$ \\
\hline & & $\mathrm{C}$ & $\mathrm{A}$ & C & $\mathrm{A}$ & Tvalue & & $\mathrm{C}$ & $\mathrm{A}$ & $\mathrm{C}$ & $A$ & Tvalue & \\
\hline
\end{tabular}




\begin{tabular}{|c|c|c|c|c|c|c|c|c|c|c|c|c|c|}
\hline 1 & $\begin{array}{l}\text { Before } \\
\text { effort- } \\
\text { station } 1\end{array}$ & 8.700 & $\begin{array}{l}0.41 \\
2\end{array}$ & 9.100 & $\begin{array}{l}0.65 \\
2\end{array}$ & 1.160 & $\begin{array}{l}\text { insignifican } \\
\text { ce }\end{array}$ & 2.800 & $\begin{array}{l}0.57 \\
0\end{array}$ & $\begin{array}{l}2.44 \\
0\end{array}$ & $\begin{array}{l}0.45 \\
6\end{array}$ & 1.103 & $\begin{array}{l}\text { insignifican } \\
\text { ce }\end{array}$ \\
\hline 2 & $\begin{array}{l}\text { Station 1- } \\
\text { station } 2\end{array}$ & 9.100 & $\begin{array}{l}0.65 \\
2 \\
\end{array}$ & 9.200 & $\begin{array}{l}0.57 \\
0 \\
\end{array}$ & 0.258 & $\begin{array}{l}\text { insignifican } \\
\text { ce }\end{array}$ & 2.440 & $\begin{array}{l}0.45 \\
6 \\
\end{array}$ & $\begin{array}{l}2.42 \\
0 \\
\end{array}$ & $\begin{array}{l}0.44 \\
9 \\
\end{array}$ & 0.070 & $\begin{array}{l}\text { insignifican } \\
\mathrm{ce}\end{array}$ \\
\hline 3 & $\begin{array}{l}\text { Station2- } \\
\text { station3 }\end{array}$ & 9.200 & $\begin{array}{l}0.57 \\
0 \\
\end{array}$ & 9.400 & $\begin{array}{l}0.41 \\
8 \\
\end{array}$ & 0.632 & $\begin{array}{l}\text { insignifican } \\
\text { ce }\end{array}$ & 2.420 & $\begin{array}{l}0.44 \\
9 \\
\end{array}$ & $\begin{array}{l}2.34 \\
0 \\
\end{array}$ & $\begin{array}{l}0.42 \\
2 \\
\end{array}$ & 0.290 & $\begin{array}{l}\text { insignifican } \\
\mathrm{ce}\end{array}$ \\
\hline 4 & $\begin{array}{l}\text { Station3- } \\
\text { station4 }\end{array}$ & 9.400 & $\begin{array}{l}0.41 \\
8\end{array}$ & 9.600 & $\begin{array}{l}0.41 \\
8\end{array}$ & 0.756 & $\begin{array}{l}\text { insignifican } \\
\text { ce }\end{array}$ & 2.340 & $\begin{array}{l}0.42 \\
2 \\
\end{array}$ & $\begin{array}{l}2.20 \\
0 \\
\end{array}$ & $\begin{array}{l}0.27 \\
4 \\
\end{array}$ & 0.622 & $\begin{array}{l}\text { insignifican } \\
\text { ce }\end{array}$ \\
\hline 5 & $\begin{array}{l}\text { Station4- } \\
\text { station5 }\end{array}$ & 9.600 & $\begin{array}{l}0.41 \\
8\end{array}$ & 9.700 & $\begin{array}{l}0.44 \\
7\end{array}$ & 0.365 & $\begin{array}{l}\text { insignifican } \\
\text { ce }\end{array}$ & 2.200 & $\begin{array}{l}0.27 \\
4\end{array}$ & $\begin{array}{l}2.00 \\
0\end{array}$ & $\begin{array}{l}0.14 \\
1\end{array}$ & 1.451 & $\begin{array}{l}\text { insignifican } \\
\text { ce }\end{array}$ \\
\hline 6 & $\begin{array}{l}\text { Station5- } \\
\text { station5 }\end{array}$ & 9.700 & $\begin{array}{l}0.44 \\
7\end{array}$ & 9.900 & $\begin{array}{l}0.82 \\
2\end{array}$ & 0.478 & $\begin{array}{l}\text { insignifican } \\
\text { ce }\end{array}$ & 2.000 & $\begin{array}{l}0.14 \\
1\end{array}$ & $\begin{array}{l}1.92 \\
0\end{array}$ & $\begin{array}{l}0.11 \\
0\end{array}$ & 1.000 & $\begin{array}{l}\text { insignifican } \\
\text { ce }\end{array}$ \\
\hline 7 & $\begin{array}{l}\text { Station6- } \\
\text { station7 }\end{array}$ & 9.900 & $\begin{array}{l}0.82 \\
2 \\
\end{array}$ & $\begin{array}{l}10.30 \\
0\end{array}$ & $\begin{array}{l}0.83 \\
7\end{array}$ & 0.763 & $\begin{array}{l}\text { insignifican } \\
\text { ce }\end{array}$ & 1.920 & $\begin{array}{l}0.11 \\
0\end{array}$ & $\begin{array}{l}1.72 \\
0\end{array}$ & $\begin{array}{l}0.21 \\
7\end{array}$ & 1.841 & $\begin{array}{l}\text { insignifican } \\
\text { ce }\end{array}$ \\
\hline 8 & $\begin{array}{l}\text { Station7- } \\
\text { end of } \\
\text { effort }\end{array}$ & $\begin{array}{l}10.30 \\
0\end{array}$ & $\begin{array}{l}0.83 \\
7\end{array}$ & $\begin{array}{l}10.50 \\
0\end{array}$ & $\begin{array}{l}0.50 \\
0\end{array}$ & 0.459 & $\begin{array}{l}\text { insignifican } \\
\text { ce }\end{array}$ & 1.720 & $\begin{array}{l}0.21 \\
7\end{array}$ & $\begin{array}{l}1.66 \\
0\end{array}$ & $\begin{array}{l}0.21 \\
9\end{array}$ & 0.435 & $\begin{array}{l}\text { insignifican } \\
\text { ce }\end{array}$ \\
\hline
\end{tabular}

The tabular T value at freedom degree is (8) at significance level $(0.05)$ is (2.306). Table (2) shows the differences among the means before the effort and during the race at the drinking stations, and in the end of the race in the biochemical variables. The researcher finds that the reasons of these results are the biochemical variables that are affected by the effort of the race, which is of high tension and long-time period. Whenever the effort period increases, the effects increase as it is shown above from station to another till the end of the race. The change is for Sodium ion $\mathrm{Na}+$ of the runners' blood and comparing it to natural level (M.MOI/I 155-136). The researcher observes that the value is within the natural limit of this variable, which reflects natural adaptability of the study sample due to continuation and increase of training under similar race effort (the adaptation of thyroid gland by absorbing $\mathrm{Na}+$ from sweat before reaching to the skin through renal tubules and compensating the lost one; $\mathrm{Na}+\mathrm{Chloride}$, through drinking liquids, and salts between the training sessions) (the reflexive $\mathrm{Na}+$ movement by transferring from inside and outside the cell which led into its decrease in blood. $\mathrm{Na}+$ plays an important role in controlling the balance of drink between blood and cell. Decrease of $\mathrm{Na}+$ leads into tachycardia). As for the variable $\mathrm{K}+$ ion, the researcher explains that it depends on the effort during the race, which is characterized by tight difference and period of continuation from one station to another. So, it needs to consume energy and affected by body internal and external temperature. So, the sweat average is affected by the overall factors that influences $\mathrm{K}+$ ion. It has an important role in distributing drink between blood and cell. Also, it has a basic role in the process of muscle contraction. It controls the organization of the Osmosis pressure and electro-effort on the cell membrane (Abdullah, 2012). Moreover, it works on the acidic and alkaline balance pressure $(\mathrm{K}+$ ion is found greatly in red blood cells more than plasma. The $\mathrm{K}+$ in muscles stimulates the nerve centres of breath, which increases lung ventilation. The neuro-muscular adaptation leads into the continuation of muscular work through the physical effort that decreases muscular tissue damage because of the athletic performance). So, (the damage increases $\mathrm{K}+$ egression of the muscles while more $\mathrm{Na}+$ conveys waste to the muscular tissues due to excretion of renal channels connected to $\mathrm{K}+$ which normalizes and balances it in serum). As for $\mathrm{Ca}+$ ion, the researcher explains that the exerted effort during the race and the Ca function that helps enzyme interactions and other metabolism interactions (the muscular contraction occurs through the effort of the muscle and nerve fibres, which stimulate and effect on the concentration of free Ca electrolyte in muscle cell in turn it stimulates membrane). The special organizing of $\mathrm{Mg}$ in the body through the biological regulators remains at its normal level even if it increases, the increase is temporal and gets back to its normal level. That is why we have insignificant relation (despite that the overall concentration of $\mathrm{Mg}$ is about $(1.8 \mathrm{ml})$, more than half of the amount is associated with plasma proteins. So, the ion concentration of free Mg remains in an average of $0.8 \mathrm{ml}$ ). The daily amount of $\mathrm{Mg}$, its function is in thread granules that include breath enzymes and 
contribute to accelerate of metabolism process. Half of the daily amount of the $\mathrm{Mg}$ is (125-150mg/daily) while the kidney in the normal cases empties about $15 \%$ of $\mathrm{Mg}$ in glomerular filtration. It may noticeably increase $\mathrm{Mg}$ excretion because of the $\mathrm{Mg}$ overflow $\mathrm{Mg}$ and may decrease into zero when depleted. It must regularly regulate the $\mathrm{Mg}$ concentration in the body because the biochemical process using it to activate many enzymes.

Table 3. The correlations among variables before effort and different stations.

\begin{tabular}{|l|l|l|l|l|l|l|l|l|}
\hline $\begin{array}{l}\text { Stations } \\
------ \\
\text { variables }\end{array}$ & $\begin{array}{l}\text { First } \\
\text { Station }\end{array}$ & $\begin{array}{l}\text { Second } \\
\text { station }\end{array}$ & $\begin{array}{l}\text { Third } \\
\text { station }\end{array}$ & $\begin{array}{l}\text { Fourth } \\
\text { station }\end{array}$ & $\begin{array}{l}\text { Fifth } \\
\text { station }\end{array}$ & $\begin{array}{l}\text { Sixth } \\
\text { station }\end{array}$ & $\begin{array}{l}\text { Seventh } \\
\text { station }\end{array}$ & $\begin{array}{l}\text { Eighth } \\
\text { station }\end{array}$ \\
\hline $\mathrm{Na}$ & 0.235 & 0.539 & 0.160 & $0.718^{*}$ & $0.927^{*}$ & $0.787^{*}$ & 0.066 & 0.587 \\
\hline $\mathrm{K}$ & 0.570 & 0.009 & 0.173 & 0.361 & 0.514 & 0.574 & 0.000 & 0.587 \\
\hline $\mathrm{Ca}$. & $0.651^{*}$ & $0.638^{*}$ & 0.580 & 0.435 & 0.203 & $0.701^{*}$ & 0.254 & 0.424 \\
\hline $\mathrm{Mg}$ & $0.904^{*}$ & 0.605 & 0.613 & $0.721^{*}$ & 0.310 & 0.480 & $0.668^{*}$ & 0.480 \\
\hline
\end{tabular}

- The value of tabular $(R)$ is $(0.632)$ with freedom degree $(9-1=8)$ and at a significance level of $(0.5)$.

- Significance level.

Table 4. The percentage of contribution among variables before effort and different stations

\begin{tabular}{|l|l|l|l|l|l|l|l|l|l|}
\hline $\begin{array}{l}\text { Stations } \\
\text { variables }\end{array}$ & $\begin{array}{l}\text { First } \\
\text { Station }\end{array}$ & $\begin{array}{l}\text { Second } \\
\text { station }\end{array}$ & $\begin{array}{l}\text { Third } \\
\text { station }\end{array}$ & $\begin{array}{l}\text { Fourth } \\
\text { station }\end{array}$ & $\begin{array}{l}\text { Fifth } \\
\text { station }\end{array}$ & $\begin{array}{l}\text { Sixth } \\
\text { station }\end{array}$ & $\begin{array}{l}\text { Seventh } \\
\text { station }\end{array}$ & $\begin{array}{l}\text { Eighth } \\
\text { station }\end{array}$ & centre \\
\hline $\mathrm{Na}$ & 0.055 & 0.290 & 0.025 & 0.515 & 0.859 & 0.619 & 0.004 & 0.344 & Second \\
\hline $\mathrm{K}$ & 0.324 & 0.000 & 0.029 & 0.130 & 0.264 & 0.329 & 0.000 & 0.344 & Fourth \\
\hline $\mathrm{Ca}$. & 0.423 & 0.407 & 0.336 & 0.041 & 0.041 & 0.491 & 0.064 & 0.179 & Third \\
\hline $\mathrm{Mg}$ & 0.817 & 0.366 & 0.375 & 0.519 & 0.096 & 0.230 & 0.459 & 0.230 & First \\
\hline
\end{tabular}

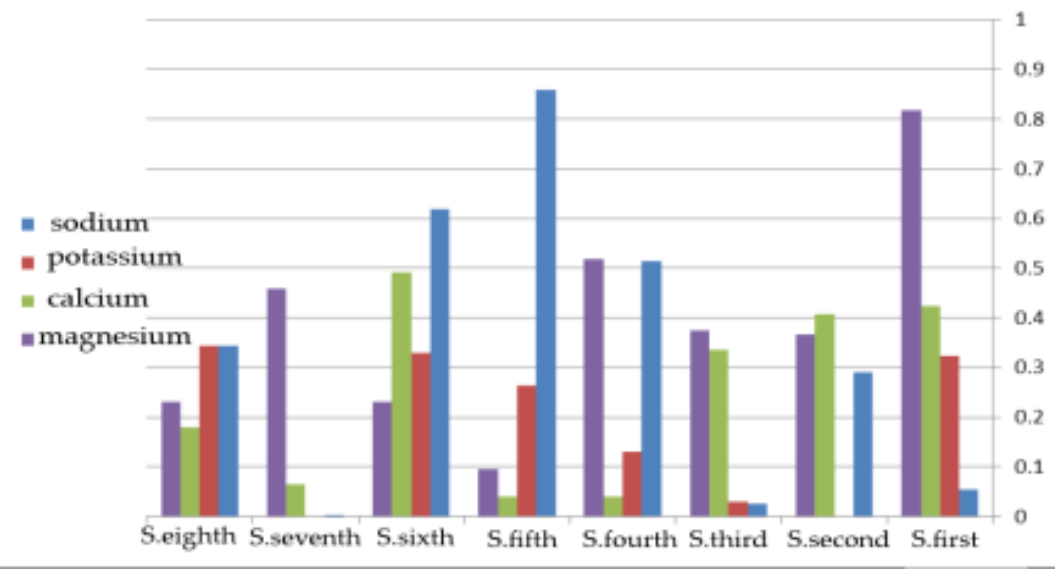

Figure 1. The contribution based on importance.

Through table (2and 3), figure (1) and the study variables (by stepwise regression), the arrangement of biochemical ions is organized according to the significance of drinking stations. Through what is mentioned above, we found that $\mathrm{Mg}+$ ion increases the function of the runner's organs, which in turn increases the speed of biochemical interactions to break sugar in the blood to generate energy of the muscles in addition to the nervous system activity performance. $\mathrm{Mg}$ is considered as a stimulant for many of chemical interactions inside cells especially those related to sugar metabolism. Mg is found in weak concentration out of the cells 
about (1.8-2.5ml). Its concentration decreases out of the nervous cells and the skeletal muscles. It is possible to limit the last effect by entering $\mathrm{Ca}$. and due to the low concentration of $\mathrm{Mg}$. in nervous system and the expansion of peripheral and organizational veins and organizing heart especially after severe myocardial infarction. ${ }^{7}$ While $\mathrm{Na}+$ contributes more actively during nervous and muscular contraction where some found out of the cell and other inside it. This percentage is balanced between losing and compensating within the natural limits of mineral salts during the rest and effort. ( $\mathrm{Na}+$ and salts osmosis motion to inside and outside the cell conveys $\mathrm{Na}+$ into blood that results the runner takes some liquids and salts before, during and after the effort of the race leading into balance between losing and compensating to preserve $\mathrm{Na}+$ percentage in the body). $\mathrm{Ca}+$ ion ranked third because of the competition between the racers in the last three stations where it leads directly into fatigue due of the energy loss of the racer during the race that requires power and speed of movement to reach the end line of the race. Alawi and Alfatah refer to that (any misbalance in the distribution of mineral salts concentration on the both sides of muscular fibre membrane, which causes muscle spasms because of the high effort of body). Also, Mohammed confirmed that (when the nerve impulse reaches into the muscle fibres, a new chemical change and new distribution of ions in the stimulated fibre). $\mathrm{K}+$ is fourth in the importance as effort during the race because of $\mathrm{K}+$ variable regarded as an important mineral element in the human body. $\mathrm{K}+$ has a great effect during the sport activity where it is found inside and outside of the cell. This percentage is balanced between losing and compensating within the natural limit of mineral salts during the rest and effort. Abdullah confirmed that (kidney is responsible of organizing $\mathrm{K}+$ through the filtration process, reabsorption, and discharge. the filtration depends on the average of discharge and reabsorbing of $\mathrm{K}+$ was limited and happened when the $\mathrm{K}+$ in liquid out of the cell is low).

\section{CONCLUSIONS}

1. Marathon activity has a great effect on the biochemical variables ( $\mathrm{Na} . \mathrm{Ca} . \mathrm{Mg} . \mathrm{K}$ ).

2. The effort of the race decreases the levels of biochemical variables in comparison to the levels before effort. But they remain within the natural limits during the effort according to race tolerance and power.

\section{RECOMMENDATIONS}

1. Conduct modern studies on biochemical variables in team and individual games.

2. Conduct other analytical studies on the physiological and climate variables affecting on the marathon runner's activity.

\section{REFERENCES}

Arthac .cuton, M d f, (2001), Medical physiology under company 20thed U.S.A P: 972.

Australia sports Medicine foundation, (1994), The Textbook of sports nutrition Hightstown,NJ, Mc Craw.Hill.

D.W.Edington, (1987), the biology of physical Activity U.S.A, P: 201.

Jabes R.PoartMosn, (1984), Exercise Renal Function in June sports medicine vol-1- P: 150.

Jamshidinaeini, Y., Akbari, M.E., Abdollahi, M., Ajami, M. \& Davoodi, S.H. (2016). Vitamin D Status and

Risk of Breast Cancer in Iranian Women: A Case-Control Study. Journal of the American College of Nutrition, no 35(7). 639-646. https://doi.org/10.1080/07315724.2015.1127786

Giton\& Hall, (1997), Translated by SadekAlhalalil: encyclopedia of physiological medicine. WHO. MiddleEast regional office, Pp.503-1078. 
Mufti Ibrahim Hamada, (2001), Modern Athletic Training - planning, application, and competition. Second edition. Arabic thinking house, Cairo, p21.

Mohammed Hasan Alawi \&Albo Alola Abdulfatah, (1988). The Physiology of Athletic Training. Arabic Fikr House. Cairo, p413.

Robert K. Murray, (1997), Harpers Biochehemistry 25thed middle East East Edition, U.K P:688.

Sameah Khalil Mohammed (2008). Athletic Physiology Principles. Nas Co. Printing. Baghdad, p107.

Shatoi Abdullah, (2012). Parts Function Science. Almaserra House for Publication \&Distribution. Oman. P 68. 